\title{
Adsorption isotherms and isosteric heat in Coffea arabica beans ${ }^{1}$
}

\author{
Samuel Gonçalves Ferreira dos Santos², Daniel Pereira da Silva², \\ Jefferson Kran Sarti², Vinícius Gonçalves Almeida ${ }^{2}$, Renato Souza Rodovalho ${ }^{2}$
}

\begin{abstract}
The knowledge of the adsorption hygroscopic equilibrium in coffee is pertinent for the adequacy of its storage, thus ensuring the quality of the product to the end consumer. The present study aimed to determine the adsorption isotherms of Arabica coffee (Acauã Novo cultivar) beans at the temperatures of $30{ }^{\circ} \mathrm{C}, 40{ }^{\circ} \mathrm{C}, 50{ }^{\circ} \mathrm{C}$ and $60^{\circ} \mathrm{C}$, as well as the integral adsorption isosteric heat. The equilibrium moisture contents were obtained by the gravimetric static method, using water activities between 0.10 and 0.83 (decimal). From the obtained data, several mathematical models were fitted to represent the adsorption isotherms. The statistical criteria for selecting the best model were the coefficient of determination, estimated mean standard error, relative mean error and distribution of residues. The Peleg model was the one that best represented the adsorption isotherms of the Arabica coffee beans under the studied conditions. The isotherms showed a sigmoidal type II shape. For a constant water activity, an increase in the temperature promotes a decrease in the equilibrium moisture content of Arabica coffee beans. In a moisture content range between 0.0191 and 0.2534 (dry base), the isosteric heat values ranged from $4,042.19 \mathrm{~kJ} \mathrm{~kg}^{-1}$ to $2,395.48 \mathrm{~kJ} \mathrm{~kg}^{-1}$.
\end{abstract}

KEYWORDS: Hygroscopic equilibrium, mathematical modeling, moisture content.

\section{INTRODUCTION}

Coffee cultivation is crucial to the economy of many countries, being responsible for job creation in various parts of the world. In Brazil, the coffee production chain is responsible for more than eight million jobs, providing income and access to health and education for workers and their families (Brasil 2017).

As the longevity of coffee beans highly depends on the availability of water inside them, increasing or decreasing the moisture content of coffee beans may impair their storage, due to the

\section{RESUMO}

Isotermas de adsorção e

calor isostérico em grãos de Coffea arabica

O conhecimento do equilíbrio higroscópio de adsorção em café é pertinente para a adequação de seu armazenamento, garantindo a qualidade do produto até o consumidor final. Objetivouse determinar as isotermas de adsorção de grãos de café Arábica (cultivar Acauã Novo) nas temperaturas de $30^{\circ} \mathrm{C}, 40^{\circ} \mathrm{C}, 50^{\circ} \mathrm{C}$ e $60^{\circ} \mathrm{C}$, bem como o calor isostérico integral de adsorção. Os teores de água de equilíbrio foram obtidos pelo método estático gravimétrico, com atividades de água entre 0,10 e 0,83 (decimal). A partir dos dados obtidos, foram ajustados diversos modelos matemáticos para representar as isotermas de adsorção. Os critérios estatísticos para a seleção do melhor modelo foram o coeficiente de determinação, erro médio estimado, erro médio relativo e a distribuição de resíduos. O modelo de Peleg foi o que melhor representou as isotermas de adsorção dos grãos de café Arábica nas condições estudadas. As isotermas apresentaram formato sigmoidal tipo II. Sob atividade de água constante, o aumento da temperatura promove diminuição no equilíbrio do teor de umidade em grãos de café Arábica. Os valores de calor isostérico com teor de água entre 0,0191 e 0,2534 (base seca) variaram de $4.042,19 \mathrm{~kJ} \mathrm{~kg}^{-1}$ a $2.395,48 \mathrm{~kJ} \mathrm{~kg}^{-1}$.

PALAVRAS-CHAVE: Equilíbrio higroscópico, modelagem matemática, teor de água.

appearance of microorganisms and insects (Corrêa et al. 2016, Bakhtavar et al. 2019). In this context, adsorption isotherms are defined as the relationship between the moisture content and the water activity of a given product, at a constant temperature. This knowledge contributes to ensure an adequate storage of agricultural products (Bustos-Vanegas et al. 2018). In addition, sorption isotherms provide information on the sorption mechanisms of water with product constituents (Corrêa et al. 2015), serving as a quality parameter for the harvest and post-harvest operations of agricultural products. 
It is possible to obtain adsorption isosteric heat using isotherms. The knowledge of this thermodynamic parameter is essential in studies on drying and storage of agricultural products. It serves to estimate the energy requirements for the drying process (Wang \& Brennan 1991). Moreover, this thermodynamic parameter provides information that allow the calculation of energy for heating and mass transfer in biological systems, thus allowing a greater understanding of the water molecules properties (Goneli et al. 2016b).

This study aimed to determine the adsorption isotherms of Coffea arabica L. beans (Acauã Novo cultivar) at different harvest temperatures, under Brazilian Savannah conditions, as well as the integral adsorption isosteric heat.

\section{MATERIAL AND METHODS}

The research was developed from 02 September 2017 to 10 February 2018, at the Instituto Federal Goiano, in Ceres (UTM E $=649,582.00 \mathrm{~m}$, $\mathrm{N}=8,302,194.00 \mathrm{~m}$ and altitude of $556 \mathrm{~m}$ ), Goiás state, Brazil, where Coffea arabica L. beans (Acauã Novo cultivar) were obtained. The climate in the area is tropical, with a dry winter season, according to the Köppen-Geiger classification (Cardoso et al. 2014).

The coffee fruits were harvested manually by total untangling. They were plucked from the plant and spilled on the floor covered by a cloth. The harvested fruits had a moisture content of 1.16 (dry basis - d.b.) and, therefore, pre-drying was necessary. So, the fruits were spread on a terrace and exposed to solar radiation for $12 \mathrm{~h} /$ day, for ten days, and the fruit moisture content decreased to 0.11 (d.b.). Finally, the process of extracting the beans was carried out from the pillaging of the dried fruits. They had moisture contents of 0.08 (d.b.). The bean and fruit moisture contents were determined by gravimetry, in a greenhouse, at $105^{\circ} \mathrm{C}$, for $24 \mathrm{~h}$ (ASAE 2000).
The adsorption isotherms of Arabica coffee beans were obtained using the gravimetric static method at $30{ }^{\circ} \mathrm{C}, 40{ }^{\circ} \mathrm{C}, 50{ }^{\circ} \mathrm{C}$ and $60{ }^{\circ} \mathrm{C}$, and the water activity was obtained within the range of 0.10 to 0.83 (decimal). The beans were deposited in airtight glass containers, in which $36 \mathrm{~g}$ of beans were used for each temperature under study. There were three replicates for each water activity. Samples were weighed every $24 \mathrm{~h}$ to constant mass; that is, up to a $0.0001 \mathrm{~g}$ variation in at least three consecutive weighing procedures, indicating the hygroscopic balance of the beans. The temperature was controlled by a BOD incubator chamber. The water activity was obtained by using saturated saline solutions. Within the airtight containers, the relative humidity equaled the ambient air (Table 1).

The samples were weighed on a precision scale of four decimal digits every $24 \mathrm{~h}$, until there was a variation of $0.001 \mathrm{~g}$, which represents the hygroscopic grain balance.

The mathematical models frequently used to represent the grain hygroscopicity of agricultural products were fitted to the Arabica coffee experimental data, whose equations are presented in Table 2.

The fitting of the mathematical models was performed by nonlinear regression analysis, using the Gauss Newton method at 0.05 of probability $(t$ test). The degree of fitting was determined by the magnitude of the coefficient of determination $\left(\mathrm{R}^{2}\right)$, the relative mean error $(\mathrm{P})$, the estimated mean standard error (MSE) and the tendency of residue distribution (Rodovalho et al. 2015, Corrêa et al. 2016, Goneli et al. 2016a). The P and MSE statistics were calculated by the following expressions:

$$
\begin{aligned}
& \mathrm{P}=\frac{100}{\mathrm{n}} \sum_{\mathrm{i}=1}^{\mathrm{n}}\left(\frac{|\mathrm{Y}-\hat{\mathrm{Y}}|}{\mathrm{Y}}\right) \\
& \mathrm{MSE}=\sqrt{\frac{\sum_{\mathrm{i}=1}^{\mathrm{n}}(\mathrm{Y}-\hat{\mathrm{Y}})^{2}}{\mathrm{DF}}}
\end{aligned}
$$

Table 1. Water activity (decimal) of saturated saline solutions at $30{ }^{\circ} \mathrm{C}, 40{ }^{\circ} \mathrm{C}, 50{ }^{\circ} \mathrm{C}$ and $60{ }^{\circ} \mathrm{C}$ (Labuza et al. 1985).

\begin{tabular}{cccccc}
\hline $\begin{array}{c}\text { Temperature } \\
\left({ }^{\circ} \mathrm{C}\right)\end{array}$ & \multicolumn{5}{c}{ Salt } \\
\cline { 2 - 6 } & $\mathrm{LiCl}^{(1)}$ & $\mathrm{MgCl}_{2}^{(2)}$ & $\mathrm{Mg}\left(\mathrm{NO}_{3}\right)_{2}^{(3)}$ & $\mathrm{NaCl}^{(4)}$ & $\mathrm{KCl}^{(5)}$ \\
\hline 30 & 0.11 & 0.33 & 0.52 & 0.77 & 0.83 \\
40 & 0.11 & 0.34 & 0.50 & 0.73 & 0.81 \\
50 & 0.10 & 0.30 & 0.48 & 0.71 & 0.77 \\
60 & 0.10 & 0.29 & 0.47 & 0.70 & 0.75 \\
\hline
\end{tabular}

${ }^{1}$ Lithium chloride; ${ }^{2}$ magnesium chloride; ${ }^{3}$ magnesium nitrate $;{ }^{4}$ sodium chloride; ${ }^{5}$ potassium chloride. 
Table 2. Mathematical models for fitting the experimental data of equilibrium moisture content for beans under different temperature and water activity conditions.

\begin{tabular}{|c|c|}
\hline Model & Equation $^{1}$ \\
\hline Copace (Corrêa \& Almeida 1999) & $\mathrm{Xe}=\exp \left(\mathrm{a}-\mathrm{bT}-\mathrm{c} \mathrm{a}_{\mathrm{w}}\right)$ \\
\hline Sigma Copace (Teixeira et al. 2015) & $\mathrm{Xe}=\exp \left\{(\mathrm{a}-\mathrm{b} \mathrm{T})+\left[\mathrm{c} \exp \left(\mathrm{a}_{\mathrm{w}}\right)\right]\right\}$ \\
\hline Oswin (Boquet et al. 1978) & $\mathrm{Xe}=\mathrm{a}\left[\mathrm{a}_{\mathrm{w}} /\left(1-\mathrm{a}_{\mathrm{w}}\right)\right]^{\mathrm{b}}$ \\
\hline Peleg (Bonner \& Kenny 2013) & $\mathrm{Xe}=\mathrm{k}_{1}\left(\mathrm{a}_{\mathrm{w}}\right)^{\mathrm{n}_{1}}+\mathrm{k}_{2}\left(\mathrm{a}_{\mathrm{w}}\right)^{\mathrm{n}_{2}}$ \\
\hline Chen Clayton (Silva et al. 2015) & $\mathrm{Xe}=\left[-1 /(\mathrm{c} T d) \ln \left[\ln \left(\mathrm{a}_{\mathrm{w}}\right) /\left(-\mathrm{a} \mathrm{T}^{\mathrm{b}}\right)\right]\right.$ \\
\hline
\end{tabular}

where: $\mathrm{P}$ is expressed in percentage (\%); MSE is the estimated mean standard error (decimal); $n$ the number of experimental observations; $Y$ the experimentally observed value; $\hat{Y}$ the value estimated by the model; and DF the degrees of freedom of the model.

For the selection of the mathematical models, the model that obtained the highest $\mathrm{R}^{2}$, the lowest mean standard error, a P below $10 \%$, according to Mohapatra \& Rao (2005), and the random distribution of residues was recommended. As for the distribution of residues, it was considered random when the residual values are in a horizontal zone near zero.

The values for water activity $\left(a_{w}\right)$, temperature and equilibrium moisture content were obtained from coffee bean adsorption isotherms using the best fitted equation to the experimental data. The net isosteric adsorption heat (qst) values for each equilibrium moisture content were obtained according to the following equation: $\ln \left(\mathrm{a}_{\mathrm{w}}\right)=$ $\left(\Delta \mathrm{h}_{\mathrm{st}} / \mathrm{RT}\right)-(\Delta \mathrm{S} / \mathrm{R})$, where: $\mathrm{a}_{\mathrm{w}}$ is the water activity (decimal); $\mathrm{T}$ the absolute temperature (K); qst the net sorption isosteric heat $\left(\mathrm{kJ} \mathrm{kg}^{-1}\right)$; and $\mathrm{R}$ the universal gas constant $\left(8,314 \mathrm{~kJ} \mathrm{kmol}^{-1} \mathrm{~K}^{-1}\right)$. Water vapor is $0.4619 \mathrm{~kJ} \mathrm{~kg}^{-1} \mathrm{~K}^{-1}$.

The equation $\mathrm{Qst}=\Delta \mathrm{hst}+\mathrm{L}=\mathrm{a} \exp (-\mathrm{b} \mathrm{Xe})+$ $\mathrm{L}$, where $\mathrm{a}$ and $\mathrm{b}$ are the coefficients of the model, was used for the calculation of the integral adsorption isosteric heat (Qst). The latent vaporization heat of free water $\left(\mathrm{L} ; \mathrm{kJ} \mathrm{kg}^{-1}\right)$ necessary for the calculation of the Qst was obtained by the average temperature $\left(\mathrm{T} ;{ }^{\circ} \mathrm{C}\right)$, within the study range.

\section{RESULTS AND DISCUSSION}

The values of the coefficient of determination $\left(\mathrm{R}^{2}\right)$, relative mean error and estimated mean standard error for the adsorption isotherms of the Arabica coffee beans are shown in Table 3. Except for the Chen Clayton model, all models showed $\mathrm{R}^{2}$ values higher than 0.90 . However, the coefficient of determination alone is not a good criterion for selecting nonlinear equations (Corrêa et al. 2015). Therefore, it is necessary to consider other selection criteria.

The suitability of mathematical models for a physical process is inversely proportional to the relative mean standard error (Draper \& Smith 1998), where the values must be lower than $10 \%$. Thus, Table 3 evidences that, among the studied equations, only Peleg presented a P lower than $10 \%$ for all temperatures $(0.51 \%, 0.89 \%, 2.01 \%$ and $6.95 \%$, respectively for $30{ }^{\circ} \mathrm{C}, 40{ }^{\circ} \mathrm{C}, 50{ }^{\circ} \mathrm{C}$ and $\left.60{ }^{\circ} \mathrm{C}\right)$. In addition, according to Siqueira et al. (2012), the lower the mean standard error values, the better the model fits to the observed data. Peleg was the equation with the lowest mean standard error values $(0.0033,0.0040,0.0053$ and 0.0177 , respectively at $30^{\circ} \mathrm{C}, 40{ }^{\circ} \mathrm{C}, 50^{\circ} \mathrm{C}$ and $60^{\circ} \mathrm{C}$ ), thus indicating a good representativeness of the experimental data.

The distribution of residues, which consists of differences between the experimentally observed values and the values estimated by the model, allows to evaluate how the equation estimates the values of the variable under study. Normally, a model is considered acceptable if the residual values are in a near-zero horizontal zone, forming random distributions. If the residual distributions form geometric figures, they have regions where the equation underestimates or overestimates the real condition, or, if they tend to accumulate at an off-axis point, the distribution of their residues is considered biased and the model is inappropriate to represent the phenomenon under study (Corrêa et al. 2014).

Thus, it is clear that the Chen Clayton model presents a biased distribution for all the studied temperatures (Table 3 and Figure 1). Only the Peleg 
Table 3. Coefficients of determination $\left(\mathrm{R}^{2}\right)$, relative mean standard error $(\mathrm{P})$, estimated mean standard error (MSE) and residue distribution (Dist.) for Coffea arabica L. bean adsorption isotherms.

\begin{tabular}{lccccc}
\hline Model & Temperature $\left({ }^{\circ} \mathrm{C}\right)$ & $\mathrm{R}^{2}$ & $\mathrm{P}(\%)$ & MSE & Dist. \\
\hline \multirow{3}{*}{ Sigma Copace } & 30 & 0.99 & 2.99 & 0.0127 & $\mathrm{R}^{*}$ \\
& 40 & 0.99 & 7.21 & 0.0336 & $\mathrm{~B}^{* *}$ \\
& 50 & 0.99 & 5.70 & 0.0194 & $\mathrm{R}$ \\
\multirow{3}{*}{ Oswin } & 60 & 0.96 & 12.33 & 0.0351 & $\mathrm{R}$ \\
& 30 & 0.98 & 7.74 & 0.0252 & $\mathrm{~B}$ \\
& 40 & 0.96 & 12.47 & 0.0466 & $\mathrm{~B}$ \\
\multirow{3}{*}{ Peleg } & 50 & 0.98 & 14.05 & 0.0320 & $\mathrm{~B}$ \\
& 60 & 0.95 & 23.58 & 0.0476 & $\mathrm{~B}$ \\
\hline \multirow{4}{*}{ Copace } & 30 & 0.99 & 0.51 & 0.0033 & $\mathrm{R}$ \\
& 40 & 0.99 & 0.89 & 0.0040 & $\mathrm{R}$ \\
& 50 & 0.99 & 2.01 & 0.0053 & $\mathrm{R}$ \\
& 60 & 0.99 & 6.95 & 0.0177 & $\mathrm{R}$ \\
\hline \multirow{3}{*}{ Chen Clayton } & 30 & 0.98 & 7.59 & 0.0306 & $\mathrm{~B}$ \\
& 40 & 0.95 & 11.77 & 0.0499 & $\mathrm{~B}$ \\
& 50 & 0.98 & 11.45 & 0.0336 & $\mathrm{~B}$ \\
& 60 & 0.95 & 19.47 & 0.0473 & $\mathrm{~B}$ \\
\hline
\end{tabular}

* Random; ** biased.

model presented a random distribution for all the temperatures under study, since the residual values were in a zone close to zero (Table 3 and Figure 2).

Because it presents the best statistical results, the Peleg model was chosen to represent the adsorption isotherms of the Arabica coffee beans at $30{ }^{\circ} \mathrm{C}, 40{ }^{\circ} \mathrm{C}, 50{ }^{\circ} \mathrm{C}$ and $60{ }^{\circ} \mathrm{C}$. Henao et al. (2009), who worked with equilibrium moisture of husked cherry coffee, also recommended the Peleg model. According to the authors, the Peleg model was chosen for the calculation of the equilibrium moisture of husked cherry coffee because it presents the best statistical indicators. In addition, this equation has also been recommended to represent the hygroscopic balance of green tea powder and green tea granules (Sinija \& Mishra 2008).

The Peleg coefficients are described in Table 4, according to the studied temperatures $\left(30^{\circ} \mathrm{C}, 40^{\circ} \mathrm{C}\right.$, $50{ }^{\circ} \mathrm{C}$ and $60^{\circ} \mathrm{C}$ ). All coefficients were significant at $5 \%$ of probability by the $t$ test, indicating that this model is the most appropriate to represent the adsorption isotherms of Arabica coffee beans under the studied conditions.

Figure 3 shows the experimental values for the equilibrium moisture content of Arabica coffee beans obtained by adsorption and the values estimated by the Peleg model, evidencing that, for a constant water activity, the values of hygroscopic
(A)

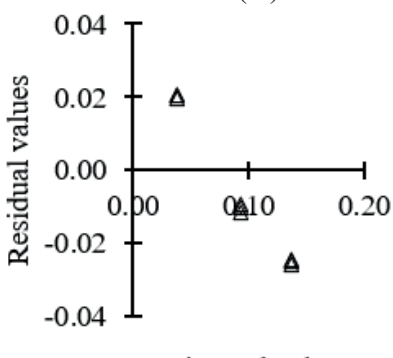

Estimated values
(B)

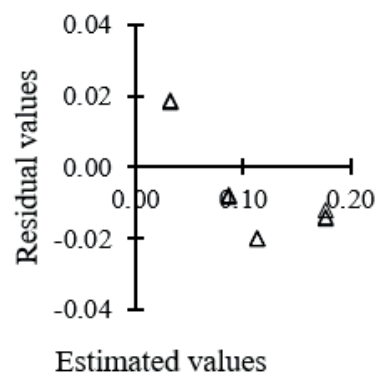

(C)

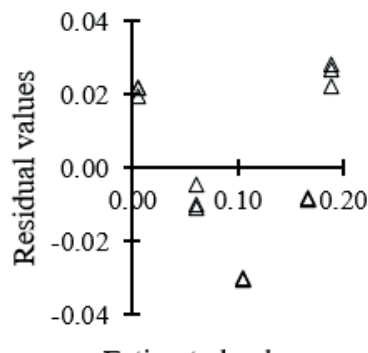

Estimated values
(D)

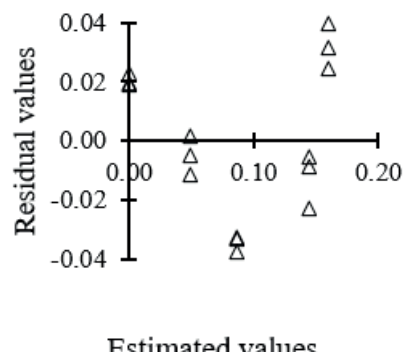

Figure 1. Behavior of the biased residue distribution by the Chen Clayton model at $30{ }^{\circ} \mathrm{C}(\mathrm{A}), 40{ }^{\circ} \mathrm{C}(\mathrm{B}), 50{ }^{\circ} \mathrm{C}(\mathrm{C})$ and $60{ }^{\circ} \mathrm{C}(\mathrm{D})$. 
(A)

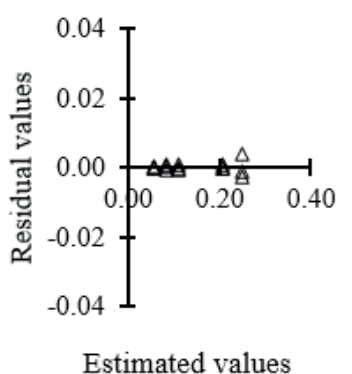

(B)

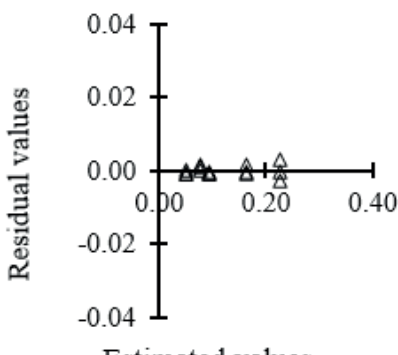

(C)

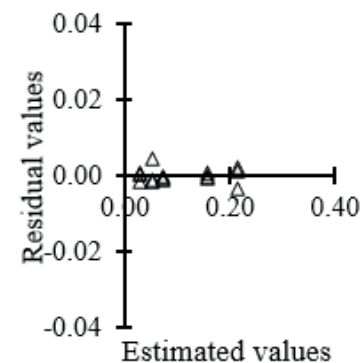

(D)

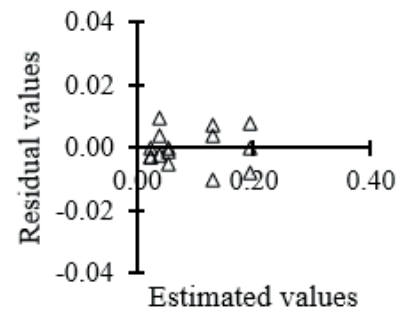

Figure 2. Behavior of the random residue distribution by the Peleg model at $30^{\circ} \mathrm{C}(\mathrm{A}), 40{ }^{\circ} \mathrm{C}(\mathrm{B}), 50{ }^{\circ} \mathrm{C}(\mathrm{C})$ and $60{ }^{\circ} \mathrm{C}(\mathrm{D})$.

Table 4. Coefficients of the Peleg model for the adsorption process of Coffea arabica L. beans, Acauã Novo cultivar, at different temperatures.

\begin{tabular}{|c|c|c|c|c|}
\hline \multirow{2}{*}{ Parameters } & \multicolumn{4}{|c|}{ - Temperature $\left({ }^{\circ} \mathrm{C}\right)$} \\
\hline & 30 & 40 & 50 & 60 \\
\hline $\mathrm{k}_{1}$ & $0.332040^{*}$ & $0.645183 *$ & $0.723368^{*}$ & $1.981901^{*}$ \\
\hline $\mathrm{n}_{1}$ & $4.448578^{*}$ & $7.879680^{*}$ & $6.874798^{*}$ & $9.689509^{*}$ \\
\hline $\mathrm{k}_{2}$ & $0.110612 *$ & $0.119512 *$ & $0.102311 *$ & $0.080230 *$ \\
\hline $\mathrm{n}_{2}$ & $0.289656^{*}$ & $0.379245^{*}$ & $0.568797 *$ & $0.545060 *$ \\
\hline
\end{tabular}

* Significant at $5 \%$ by the t-test; $\mathrm{k}_{\mathrm{l}}, \mathrm{n}_{\mathrm{l}}, \mathrm{k}_{2}, \mathrm{n}_{2}$ : coefficients of the model.

equilibrium moisture content decrease with the increase in temperature, following the tendency of most agricultural products (Smaniotto et al. 2012, Zeymer et al. 2017).

The adsorption isotherms of the Arabica coffee beans estimated by the Peleg model have a sigmoidal shape (Figure 3), which is characteristic of type II curves (Brunauer et al. 1938) and is considered the standard for agricultural products. Henao et al. (2009) obtained similar results, where the sorption isotherms of husked cherry coffee presented a sigmoidal shape, which is typical of foods and biological materials. Figure 3 also evidences that, at a given air temperature, the increase in water activity allows the increase in the grain equilibrium moisture content, due to the volume of water available in the sorption ambient air. This is due to the increased vapor pressure in the air causing a greater movement of water into the grain (Goneli et al. 2010). The same behavior was observed in quinoa seeds and Coffea canephora Pierre beans (Corrêa et al. 2014, BustosVanegas et al. 2018).

The values for integral adsorption isosteric heat (Qst), in function of the equilibrium moisture content, are shown in Figure 4. The Qst equation satisfactorily fitted the description of the phenomenon, presenting a $\mathrm{R}^{2}$ equivalent to 0.94 and being significant at $1 \%$ of probability by the t test. The Qst of the Arabica coffee beans ranged from $4,042.19 \mathrm{~kJ} \mathrm{~kg}^{-1}$ to $2,395.48 \mathrm{~kJ} \mathrm{~kg}^{-1}$, within the moisture content range of 0.0191 to 0.2534 (d.b.). Figure 4 also evidences that the reduction in moisture content leads to an increase in the energy required to remove water from Arabica coffee beans, which is represented by the obtained Qst values (Resende et al. 2006, Sousa et al. 2016).

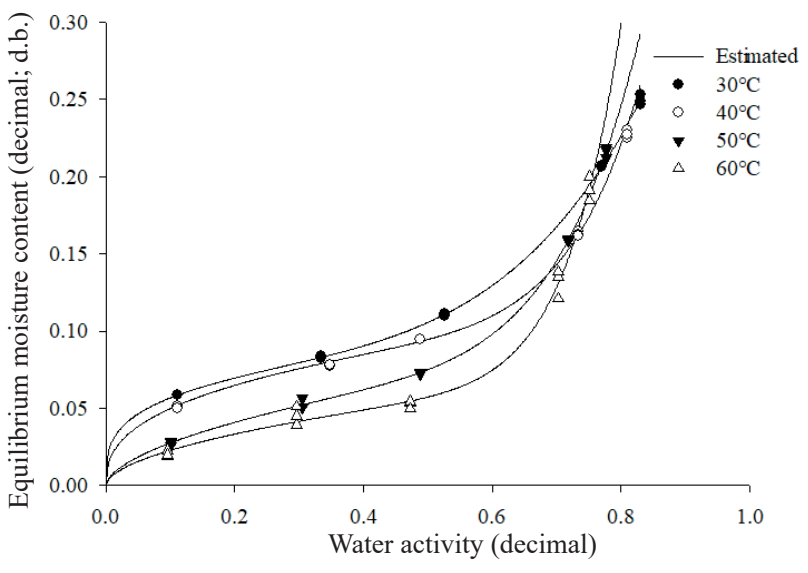

Figure 3. Grain adsorption isotherms of Coffea arabica L., Acauã Novo cultivar, estimated by the Peleg model. 


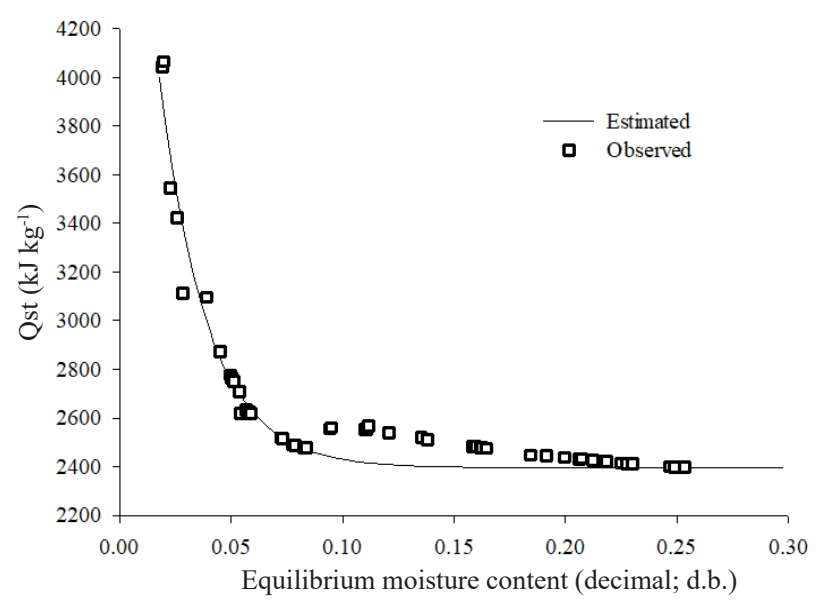

Figure 4. Estimated and observed values of adsorption isosteric heat (Qst), as a function of the equilibrium moisture content, for Coffea arabica L. beans, Acauã Novo cultivar.

\section{CONCLUSIONS}

1. The Peleg model best represents the adsorption isotherms of Coffea arabica L. beans under the studied conditions. The isotherms show a sigmoidal type II shape;

2. For a constant water activity, an increasing temperature promotes a decrease in the equilibrium moisture content of Arabica beans;

3. For a moisture content range between 0.0191 and 0.2534 (d.b.), the isosteric heat values ranged from $4,042.19 \mathrm{~kJ} \mathrm{~kg}^{-1}$ to $2,395.48 \mathrm{~kJ} \mathrm{~kg}^{-1}$.

\section{ACKNOWLEDGMENTS}

To the Instituto Federal Goiano (Campus Ceres), Fundação de Amparo à Pesquisa do Estado de Goiás (FAPEG) and Conselho Nacional de Desenvolvimento Científico e Tecnológico (CNPq), for the support and encouragement of this research.

\section{REFERENCES}

AMERICAN SOCIETY OF AGRICULTURAL ENGINEERS (ASAE). Moisture measurementungrounded grains and seeds. St. Joseph: ASAE, 2000.

BAKHTAVAR, M. A.; AFZAL, I.; BASRA, S. M. A. Moisture adsorption isotherms and quality of seeds stored in conventional packaging materials and hermetic super bag. Plos One, v. 14, n. 2, p. 1-11, 2019.

BONNER, I. J.; KENNEY, K. L. Moisture sorption characteristics and modeling of energy sorghum (Sorgum bicolor (L.) Moench). Journal of Stored Products Research, v. 52, n. 1, p. 128-136, 2013.

BOQUET, R.; CHIRIFE, J.; IGLESIAS, H. A. Equations for fitting water sorption isotherms of foods: II. Evaluation of various two-parameter models. Journal of Food Technology, v. 13, n. 4, p. 319-327, 1978.

BRASIL. Ministério da Agricultura, Pecuária e Abastecimento. Café no Brasil. 2017. Disponível em: http://www.agricultura.gov.br/assuntos/politica-agricola/ cafe/cafeicultura-brasileira. Acesso em: 15 jan. 2019.

BRUNAUER, S.; EMMETT, P. H.; TELlER, E. Adsorption of gases in multimolecular layer. Journal of the American Chemistry Society, v. 60, n. 1, p. 309-312, 1938.

BUSTOS-VANEGAS, J. D.; CORRÊA, P. C.; ZEYMER, J. S.; BAPTESTINI, F. M.; CAMPOS, R. C. Moisture sorption isotherms of quinoa seeds: thermodynamic analysis. Engenharia Agrícola, v. 38, n. 6, p. 941-950, 2018.

CARDOSO, M. R. D.; MARCUZZO, F. F. N.; BARROS, J. B. Classificação climática de Köpper-Geiger para o estado de Goiás e o Distrito Federal. Acta Geográfica, v. 8, n. 16, p. 40-55, 2014.

CORRÊA, P. C.; ALMEIDA, F. de A. C. Comparação de modelos matemáticos de equilíbrio higroscópico para semente e fibra de algodão herbáceo, cultivar Redenção. Revista de Oleaginosas e Fibrosas, v. 3, n. 1, p. 1-6, 1999.

CORRÊA, P. C.; REIS, M. F. T.; OLIVEIRA, G. H. H.; OLIVEIRA, A. P. L. R.; BOTELHO, F. M. Moisture desorption isotherms of cucumber seeds: modeling and thermodynamic properties. Journal of Seed Science, v. 37, n. 3, p. 218-225, 2015.

CORRÊA, P. C.; BOTELHO, F. M.; BOTELHO, S. C. C.; GONELI, A. L. D. Isotermas de sorção de água de frutos de Coffea canephora. Revista Brasileira de Engenharia Agrícola e Ambiental, v. 18, n. 10, p. 1047-1052, 2014.

CORRÊA, P. C.; OLIVEIRA, A. P. L. R.; OLIVEIRA, G. H. H.; GONELI, A. L. D. Isotermas de dessorção de sementes de beterraba. Engenharia na Agricultura, v. 24, n. 1, p. 15-21, 2016.

DRAPER, N. R.; SMITH, H. Applied regression analysis. 3. ed. New York: John Wiley \& Sons, 1998.

GONELI, A. L. D.; CORRÊA, P. C.; OLIVEIRA, G. H. H.; OLIVEIRA, A. P. L. R.; ORLANDO, R. C. Moisture sorption isotherms of castor beans: Part 2. Termodynamic properties. Revista Brasileira de Engenharia Agrícola e Ambiental, v. 20, n. 8, p. 757-762, 2016b.

GONELI, A. L. D.; CORRÊA, P. C.; OLIVEIRA, G. H. H.; RESENDE, O.; MAUAD, M. Moisture sorption 
isotherms of castor beans: Part 1. Mathematical modeling and hysteresis. Revista Brasileira de Engenharia Agrícola e Ambiental, v. 20, n. 8, p. 751-756, 2016a.

GONELI, A. L. D.; OLIVEIRA, G. H. H.; CORREAA, P. C.; BOTELHO, F. M. Water desorption and thermodynamic properties of okra seeds. Transactions of the ASABE, v. 53, n. 1, p. 191-197, 2010.

HENAO, J. D.; QUEIROZ, M. R.; HAJ-ISA, N. M. A. Umidade de equilíbrio de café cereja descascado baseada em métodos estático e dinâmico. Revista Brasileira de Engenharia Agrícola e Ambiental, v. 13, n. 4, p. 470-476, 2009.

LABUZA, T. P.; KAANANE, A.; CHEN, J. Y. Effect of temperature on the moisture sorption isotherms and water activity shift of two dehydrated foods. Journal of Food Science, v. 50, n. 2, p. 385-391, 1985.

MOHAPATRA, D.; RAO, P. S. A thin layer drying model of parboiled wheat. Journal of Food Engineering, v. 66, n. 4, p. 513-518, 2005.

RESENDE, O.; CORRÊA, P. C.; GONELI, A. L. D.; RIBEIRO, D. M. Isotermas e calor isostérico de sorção do feijão. Ciência e Tecnologia de Alimentos, v. 26, n. 3, p. 626-631, 2006.

RODOVALHO, R. S.; WAKSON, H.; SILVA, I. L.; ROSSETTO, C. A. V. Isotermas de sorção dos grãos de pimenta bode. Revista de Agrotecnologia, v. 6, n. 1, p. 80-101, 2015.

SILVA, H. W.; COSTA, L. M.; RESENDE, O.; OLIVEIRA, D. E. C.; SOARES, R. S.; VALE, L. S. R. Higroscopicidade das sementes de pimenta (Capsicum chinense L.). Revista
Brasileira de Engenharia Agrícola e Ambiental, v. 19, n. 8, p. 780-784, 2015.

SINIJA, V. R.; MISHRA, H. N. Moisture sorption isotherms and heat of sorption of instant (soluble) green tea powder and green tea granules. Journal of Food Engineering, v. 86, n. 4, p. 494-500, 2008.

SIQUEIRA, V. C.; RESENDE, O.; CHAVES, T. H. Drying kinetics of jatropha seeds. Revista Ceres, v. 59, n. 2, p. 171-177, 2012.

SMANIOTTO, T. A. S.; RESENDE, O.; OLIVEIRA, D. E. C.; SOUSA, K. A.; CAMPOS, R. C. Isotermas e calor latente de dessorção dos grãos de milho da cultivar AG 7088. Revista Brasileira de Milho e Sorgo, v. 11, n. 3, p. 312-322, 2012.

SOUSA, K. A.; RESENDE, O.; CARVALHO, B. S. Determination of desorption isotherms, latent heat and isosteric heat of pequi diaspore. Revista Brasileira de Engenharia Agricola e Ambiental, v. 20, n. 5, p. 493-498, 2016.

TEIXEIRA, L. P.; ANDRADE, E. T.; ESPINDOLA, J. Z.; PEREIRA, R. G. Determinação do equilíbrio higroscópico e do calor isostérico do bagaço de cana-de-açúcar. Journal of the Brazilian Association of Agricultural Engineering, v. 35, n. 3, p. 555-566, 2015.

WANG, N.; BRENNAN, J. G. Moisture sorption isotherm characteristics of potato at four temperatures. Journal of Food Engineering, v. 14, n. 4, p. 269-287, 1991.

ZEYMER, J. S.; CORRÊA, P. C.; OLIVEIRA, G. H. H.; BAPTESTINI, F. M.; FREITAS, R. C. P. Desorption isotherms of Lactuca sativa seeds. Revista Brasileira de Engenharia Agrícola e Ambiental, v. 21, n. 8, p. 568-572, 2017. 